\title{
Measuring employees' perception in small and medium-sized enterprises: A self-assessment scale
}

\author{
Winston G. Lewis*, Kit F. Pun, Terrence R. M. Lalla \\ Faculty of Engineering, The University of The West Indies, St. Augustine, Trinidad and Tobago, West Indies
}

(Received July 19 2007, Accepted August 12 2007)

\begin{abstract}
This paper describes a self-assessment scale, the Employee Perception Scale (EPS), and investigates its reliability and validity for measuring employees' perception towards the continual improvement in small and medium-sized enterprises (SMEs). Empirical data were collected from 635 employees of 110 SMEs in manufacturing sectors in Trinidad and Tobago. With the aid of statistical software (i.e. the SPSS and LISREL), the inter-item reliability, and construct and content validities of the scale were examined. Results showed that the EPS is a reliable and valid tool in measuring the employees' perception on quality performance improvement in SMEs. The paper contributes to developing self-assessment scale in measuring employees' perceptions. It is anticipated that the findings would provide practical insights for practitioners to adopt the scale for measuring employees' perceptions in SMEs.
\end{abstract}

Keywords: employees' perception, SMEs, validity, reliability

\section{Introduction}

Many recent studies (e.g. [7, 12-16]) found that the sustained growth of small and medium-sized enterprises (SMEs) is dependent on its founder, its people and the inherent characteristics of the organisation. The characteristics of SMEs are determined by the prevailing culture of the organisations, while the strategies used are dependent on the systems and processes used. Many quality gurus (e.g. Deming, Juran, Crosby, etc.) and various business excellence frameworks (e.g. Deming Prize, European Quality Award, Malcolm Balridge National Quality Award, etc.) stressed the importance of people involvement and empowerment.

According to ISO Focus [2], many SMEs have used the ISO 9001:2000 Standard for quality system implementation. Working in tandem with this is the ISO 9004: 2000 Standard which Annex A offers guidelines for self-assessment on the performance maturity levels that has been attained with respect to the eight quality management principles ${ }^{[1]}$. Nevertheless, a lack of people management is a root cause that would prohibit SMEs to derive benefits from total quality management (TQM) implementation ${ }^{[12,13]}$. Johns and Saks ${ }^{[9]}$ define perception as the process of interpreting the messages of people's senses to provide order and meaning to the environment. Perception plays a significant part in determining whether employees are disengaged, i.e. a phenomenon where employees are at work but are minimising their work contribution. Tasker ${ }^{[24]}$ defines engagement as a beneficial two-way relationship. Disengagement can exist under conditions of poor leadership and when the level of trust between managers and employees is low ${ }^{[20]}$. There is a need for the development of an instrument that measures employees' perception towards the continual improvement of an organisation.

This paper presents the main findings of a recent survey that investigated into the employee perception issues in quality improvement and describes a 6-construct scale that is referred to as the Employee Perception Scale (EPS). With the aid of the statistical software, the inter-item reliability of the scale was computed.

\footnotetext{
*E-mail address: wlewis@eng.uwi.tt; kfpun@eng.uwi.tt; tlalla@eng.uwi.tt.
} 
Confirmatory factor analysis (CFA) was performed to examine the construct validity of the latent factors, and a subjective measure was used to determine the content validity of the EPS.

\section{Development of the employees' perception scale}

A review by Garengo et al. ${ }^{[6]}$ of eight performance measurement systems used by SMEs indicated that only two were designed specifically for SMEs, namely the Organisational Performance Measurement (OPM) model ${ }^{[5]}$ and the Integrated Performance Measurement (IPM) model for small firms ${ }^{[11]}$. In the OPM model, no mention is made of measuring employees' perception. It is based primarily on two key management constructs. The first construct describes three zones of management (i.e. strategic, tactical and operational), whereas the second construct focuses on the company's environment, using stakeholder satisfaction as the most important indicator ${ }^{[5]}$. On the other hand, the IPM model is a hybrid accounting system connecting the traditional view and the activity-based costing together in a causal chain ${ }^{[11]}$. The seven main dimensions of measures are classified as two external dimensions (i.e. financial performance and competitiveness) and five internal dimensions (i.e. costs, production factors, activities, products and revenues). It has not employees' perception as one of its dimensions.

Lewis et al. ${ }^{[14,15]}$ reviewed ten recent studies in TQM implementation in SMEs and identified six constructs incorporating 46 criteria of TQM implementation. This study extends Lewis et al.' ${ }^{[14,15]}$ study and develops the Employee Perception Scale (EPS) to measure the six constructs for continual improvement in SMEs. The scale comprises 6 constructs, namely

(1) confidence and trust in the organisation (CTO);

(2) interest in the employees' future (IEF);

(3) teaching employees to solve problems (TESP);

(4) communicating information and needs in the organisation (CINO);

(5) actively seeking employees' ideas and opinions (ASIO);

(6) recognising employees' involvement and accomplishments (REIA).

These constructs are analogous to the 'climate areas' that reflect the relationship between organisational climate and the bottom-line indicators of corporate success ${ }^{[21,22]}$. Tab. 1 shows the EPS constructs and the corresponding scale items by which the perception is to be measured.

Table 1: The EPS constructs and variables (Source: Based on [15])

\begin{tabular}{|c|c|c|}
\hline $\begin{array}{l}\text { The Six EPS Constructs/ } \\
\text { Survey Variables }\end{array}$ & $\begin{array}{l}\text { Criteria of TQM } \\
\text { implementation in SMEs }\end{array}$ & $\begin{array}{l}\text { Question Items of the } \\
\text { Employee Perception Survey }\end{array}$ \\
\hline \multirow{11}{*}{$\begin{array}{l}\text { 1. Confidence and } \\
\text { trust in the } \\
\text { organisation (CTO) }\end{array}$} & 3. Management commitment & Q3. Management considers safety important \\
\hline & 4. Customer satisfaction & Q4. Employees feel loyalty to the organisation \\
\hline & 8. Leadership & Q14. Employees like working for this organisation \\
\hline & 17. TQM vision & $\begin{array}{l}\text { Q15. Supervisors pay adequate attention to } \\
\text { safety matters }\end{array}$ \\
\hline & 22. Customer feedback & Q26. Employees are satisfied with their jobs \\
\hline & 27. Firms characteristics & $\begin{array}{l}\text { Q27. Supervisors are supported by management in } \\
\text { their decisions affecting safe operations }\end{array}$ \\
\hline & 28. Business characteristics & $\begin{array}{l}\text { Q37. In this organisation, accidents and injuries are } \\
\text { thoroughly investigated }\end{array}$ \\
\hline & 30. Competitive strategy & $\begin{array}{l}\text { Q40. In this organisation, maintenance programs are } \\
\text { at a level to prevent accidents or incidents }\end{array}$ \\
\hline & 34. Leadership training & \\
\hline & 45. Product quality design & \\
\hline & 46. Resource management & \\
\hline \multirow{3}{*}{$\begin{array}{l}\text { 2. Interest in the } \\
\text { employees' future (IEF) }\end{array}$} & 1. Training and education & $\begin{array}{l}\text { Q5. New employees are assigned to work with } \\
\text { experienced employees for job instruction }\end{array}$ \\
\hline & $\begin{array}{l}\text { 25. Modifying organisation } \\
\text { structure }\end{array}$ & $\begin{array}{l}\text { Q13. Employees see a good future for themselves } \\
\text { in this organisation }\end{array}$ \\
\hline & 29. Social responsibility & $\begin{array}{l}\text { Q16. Off the job safety is part of the } \\
\text { organisation's safety programme }\end{array}$ \\
\hline
\end{tabular}


Table 1: Continued

\begin{tabular}{|c|c|c|}
\hline & $\begin{array}{l}\text { 35. Integrating the voice of the } \\
\text { customer and suppliers }\end{array}$ & $\begin{array}{l}\text { Q25. Employees have a feeling of security that their } \\
\text { job will be there in the future }\end{array}$ \\
\hline & 37. Customer focus & $\begin{array}{l}\text { Q28. Management insists on employees taking } \\
\text { proper care of their health }\end{array}$ \\
\hline & 43. Cultural barriers & $\begin{array}{l}\text { Q36. Supervisors have a good working knowledge } \\
\text { of safety aspects of their jobs }\end{array}$ \\
\hline & 44. Financial barriers & \\
\hline \multirow{7}{*}{$\begin{array}{l}\text { 3. Teaching employees } \\
\text { to solve problems } \\
\text { (TESP) }\end{array}$} & 7. Continuous improvement & $\begin{array}{l}\text { Q2. Supervisors provide a safety orientation } \\
\text { for newly assigned employees }\end{array}$ \\
\hline & 14. Quality awareness & $\begin{array}{l}\text { Q6. This organisation actively encourages me to } \\
\text { work safely }\end{array}$ \\
\hline & $\begin{array}{l}\text { 23. Internal business } \\
\text { performance }\end{array}$ & $\begin{array}{l}\text { Q12. Employees have had enough training to do } \\
\text { their job well }\end{array}$ \\
\hline & 24. Competitive benchmarking & $\begin{array}{l}\text { Q17. Employees receive adequate safety training } \\
\text { relevant to their jobs }\end{array}$ \\
\hline & $\begin{array}{l}\text { 33. Positive attitudes } \\
\text { towards quality }\end{array}$ & $\begin{array}{l}\text { Q24. Employees participate in inspections of } \\
\text { potential hazards }\end{array}$ \\
\hline & $\begin{array}{l}\text { 42. Contact with } \\
\text { suppliers and } \\
\text { professional associates }\end{array}$ & $\begin{array}{l}\text { Q29. Employees caution other employees about } \\
\text { unsafe practices }\end{array}$ \\
\hline & & $\begin{array}{l}\text { Q53. Employees with personal problems are } \\
\text { effectively managed by supervisors }\end{array}$ \\
\hline \multirow{9}{*}{$\begin{array}{l}\text { 4. Communicating } \\
\text { information } \\
\text { and needs in the } \\
\text { organisation (CINO) }\end{array}$} & $\begin{array}{l}\text { 2. Quality data } \\
\text { and reporting }\end{array}$ & $\begin{array}{l}\text { Q7. Safety rules are regularly reviewed } \\
\text { with employees }\end{array}$ \\
\hline & $\begin{array}{l}\text { 5. Role of } \\
\text { quality department }\end{array}$ & $\begin{array}{l}\text { Q11. Employees feel that they are given } \\
\text { enough responsibility }\end{array}$ \\
\hline & 6. Communication & $\begin{array}{l}\text { Q18. People understand the relationship between } \\
\text { their work and safety programmes }\end{array}$ \\
\hline & $\begin{array}{l}\text { 9. Information } \\
\text { and analysis }\end{array}$ & $\begin{array}{l}\text { Q23. Employees are checked on a regular } \\
\text { basis to determine whether they } \\
\text { are doing their jobs }\end{array}$ \\
\hline & $\begin{array}{l}\text { 12. Management of } \\
\text { process quality }\end{array}$ & $\begin{array}{l}\text { Q30. Employees have regular opportunities } \\
\text { to attend safety }\end{array}$ \\
\hline & 13. Business outcomes & $\begin{array}{l}\text { Q34. Information required to work more safely is } \\
\text { made available to employees }\end{array}$ \\
\hline & $\begin{array}{l}\text { 15. Review status } \\
\text { of TQM adoption }\end{array}$ & $\begin{array}{l}\text { Q38. This organisation's efforts have encouraged } \\
\text { you to work more safely }\end{array}$ \\
\hline & 39. Structure & \\
\hline & 40. Procedures & \\
\hline \multirow{8}{*}{$\begin{array}{l}\text { 5. Actively seeking } \\
\text { for employees' } \\
\text { ideas and } \\
\text { opinions (ASIO) }\end{array}$} & $\begin{array}{l}\text { 10. Strategic } \\
\text { quality planning }\end{array}$ & $\begin{array}{l}\text { Q1. Employees are influenced to promote } \\
\text { safety in the organisation }\end{array}$ \\
\hline & $\begin{array}{l}\text { 11. Human resource } \\
\text { utilisation }\end{array}$ & Q8. Employees enjoy their jobs \\
\hline & $\begin{array}{l}\text { 16. Formation of } \\
\text { steering committee }\end{array}$ & $\begin{array}{l}\text { Q10. Management operates an open } \\
\text { door policy on safety issues }\end{array}$ \\
\hline & $\begin{array}{l}\text { 19. Plan for } \\
\text { implementation }\end{array}$ & $\begin{array}{l}\text { Q19. Employees participate in the development of } \\
\text { safe work practices }\end{array}$ \\
\hline & \begin{tabular}{|l|} 
20. Determining \\
improvement projects
\end{tabular} & $\begin{array}{l}\text { Q22. Managers seek the input of employees } \\
\text { on decisions }\end{array}$ \\
\hline & $\begin{array}{l}\text { 26. Refining scope, } \\
\text { objectives, } \\
\text { methodologies }\end{array}$ & Q24 Employees partici in setting goals for safety \\
\hline & 31. Strategy process & $\begin{array}{l}\text { Q33. Employees are encouraged to bring potential } \\
\text { hazards to the attention of their supervisors }\end{array}$ \\
\hline & $\begin{array}{l}\text { 18. Identifying advocates } \\
\text { and resistors }\end{array}$ & $\begin{array}{l}\text { Q9. Employees are recognised when they do } \\
\text { a good job }\end{array}$ \\
\hline
\end{tabular}


Table 1: Continued

\begin{tabular}{l|l|l}
\hline \multirow{2}{*}{$\begin{array}{l}\text { 6. Recognising } \\
\text { employees' } \\
\text { involvement and } \\
\begin{array}{l}\text { accomplishments } \\
\text { (REIA) }\end{array}\end{array}$} & $\begin{array}{l}\text { 21. Competent } \\
\text { project teams }\end{array}$ & $\begin{array}{l}\text { Q20. Supervisors are authorised to reward } \\
\text { employees for good safety performance }\end{array}$ \\
\cline { 2 - 3 } & 32. Performance measures & $\begin{array}{l}\text { Q21. Employees feel that they can achieve } \\
\text { on their jobs }\end{array}$ \\
\cline { 2 - 3 } & 36. Performance rewards & $\begin{array}{l}\text { Q32. Safe work behaviors are recognised in } \\
\text { this organisation }\end{array}$ \\
\cline { 2 - 3 } & 8. Operational results & $\begin{array}{l}\text { Q39. Employees are clear as to } \\
\text { their responsibilities }\end{array}$ \\
\hline
\end{tabular}

\section{Conduct of an empirical study}

\subsection{Methodology of the study}

An empirical study was conducted to acquire employees' views on the use of the EPS in an integrated improvement process in SMEs. Using systematic sampling method, a targeted group of 400 organisations were invited from the major manufacturing sectors in Trinidad and Tobago. These SMEs were classified by size in terms of the number of employees hired (i.e. 300 or less) and were at different stages of implementing the ISO 9001: 2000 Standard. With respect to the 46 criteria advocated by Lewis et al. ${ }^{[14,15]}$, a structured questionnaire was designed. A Likert 5-point scale of 'strongly disagree', 'disagree', 'neutral', 'agree' and 'strongly agree' was used to answer question/scale items of the six EPS constructs. The questionnaire was sent to at least five employees (other than senior management) from individual SMEs.

With the aid of the Statistical Package for the Social Sciences (SPSS) and the Linear Structural RELationships (LISREL) software, the item-item reliability and the construct validity of the EPS were analysed. Reliability is indicated by the repeatability of the measure, while validity refers to whether the measures centre on the true measure. The Cronbach alpha was used to demonstrate inter-item reliability by internal consistency.

By matching the six EPS constructs and items to established scales, the content validity of these constructs was measured. The Confirmatory Factor Analysis (CFA) was then performed on the individual constructs. The factor loadings indicate the strength of their relationship and are referred to as validity coefficients. For determining the construct validity, the eight principles are considered as the latent factors of the EPS. It is assumed that units of measurements of the latent factors are standardised so that there will have unit variances in the population ${ }^{[10]}$. This means that the unit of measurement of each latent factor equals to its standard deviation.

The goodness of fit statistics is detailed for each construct or measurement model. A good fit exists if the chi-square to degrees of freedom ratio is less than 3 . The factor loadings or validity coefficients give an indication of the extent to which each scale item is able to measure the latent factor and also determines its validity ${ }^{[23]}$. The $R^{2}$ value is a measure of the strength of the linear relationship between the scale item and the latent factor. These values provide information about the extent to which a given scale item is able to measure its construct.

\subsection{Response rate and profile of respondents}

The EPS questionnaires were distributed to 400 SMEs in Trinidad and Tobago. A total of 110 SMEs participated the study, yielding a response rate of $28.8 \%$. Bentler and $\mathrm{Chou}^{[4]}$ suggested that a ratio of 5 cases per variable would be sufficient for normal and elliptical distributions when the latent variables have multiple indicators and that a ratio of at least 10 cases per variable would be sufficient for other distributions. Since there are six factors or variables in the analysis of the EPS, a valid response of 110 satisfies this condition.

The basic information about the sample and the informants is given in Tab. 2. This includes the SME groupings by industry and respondents. A total of 635 completed questionnaires were received from respondents of 110 participating SMEs. The major six industry groupings constituted 71 SMEs (i.e. 64.5\%) and 420 respondents (i.e. 66.2\%). In terms of the number of participating SMEs, these included 1) the printing, packaging and plastics sector (i.e.; 13.6\%), 2) the food, beverage and tobacco sector (i.e. 12.7\%), 3) the construction and accessory products sector (i.e. 10.0\%), 4) the energy and related sector (i.e. $10.0 \%$ ), 5) the assembly and related products sector (i.e. 9.1\%), and 6) the chemical and processing sector (i.e. $9.1 \%$ ).

\section{Measuring the reliability and validity of the EPS}

\subsection{Inter-item reliability}

The reliability of a scale is the degree to which the observed instrument measures the 'true' value and is free from measurement error ${ }^{[8]}$. A reliable measure provides consistent results when administered repeatedly to the same 
Table 2. The profile of SMEs by industry and respondents

\begin{tabular}{l|c|c}
\hline \multicolumn{1}{c|}{ SME Groupings by Industry } & Number of Firms Participated & Number of Respondents \\
\hline 1. Printing, packaging and plastics & $15(13.6 \%)$ & $90(14.2 \%)$ \\
2. Food, beverage and tobacco & $14(12.7 \%)$ & $88(13.9 \%)$ \\
3. Energy and energy related & $11(10.0 \%)$ & $70(11.0 \%)$ \\
4. Construction and accessory products & $11(10.0 \%)$ & $52(8.2 \%)$ \\
5. Assembly and related products & $10(9.1 \%)$ & $65(10.2 \%)$ \\
6. Chemical and processing & $10(9.1 \%)$ & $55(8.7 \%)$ \\
7. Textiles and garments & $6(5.5 \%)$ & $31(4.9 \%)$ \\
8. Transport and distribution & $6(5.5 \%)$ & $37(5.8 \%)$ \\
9. Furniture and appliances & $5(4.5 \%)$ & $26(4.1 \%)$ \\
10. Engineering services & $5(4.5 \%)$ & $32(5.0 \%)$ \\
11. Financial services & $4(3.6 \%)$ & $27(4.3 \%)$ \\
12. Distribution & $3(2.7 \%)$ & $11(1.7 \%)$ \\
13. Personal products & $3(2.7 \%)$ & $15(2.4 \%)$ \\
14. Professional services & $3(2.7 \%)$ & $14(2.2 \%)$ \\
15. Others (including business services, & $4(3.6 \%)$ & $22(3.5 \%)$ \\
\hline \multicolumn{1}{c}{ IT/electronics and telecommunications) } & $110(100 \%)$ & $635(100 \%)$ \\
\hline
\end{tabular}

group of people. The concepts of reliability and validity are related. Reliability is said to be a condition but is not sufficient to explain validity. The Cronbach alpha is used to demonstrate reliability by internal consistency called interitem reliability. It is the average of the correlation coefficient of each item with every other item. Values for the Cronbach alpha range between 0 and 1.0, with higher values indicating higher validity ${ }^{[8]}$. The minimum acceptable alpha value is 0.7 as recommended by Nunnally ${ }^{[19]}$.

In order to test the inter-item reliability of the EPS, empirical data obtained from 110 participating SMEs were solicited. Tab. 3 depicts the Cronbach Alpha scores for the six EPS constructs. The Cronbach Alpha scores for these constructs range from IEF with the lowest of 0.8000 to TESP with the highest of 0.8719 . The measures of inter-item reliability have the accepted alpha value above 0.7 , indicating that the EPS for measuring employees' perception is reliable.

Table 3. Inter-item reliability of the EPS

\begin{tabular}{l|c}
\hline \multicolumn{1}{c|}{ The Six EPS Variables } & Cronbach's Alpha \\
\hline 1. Confidence and trust in the organisation (CTO) & 0.8422 \\
2. Interest in the employees future (IEF) & 0.8000 \\
3. Teaching the employees to solve problems (TESP) & 0.8719 \\
4. Communicating information and needs in the organisation (CINO) & 0.8661 \\
5. Actively seeking for employees' ideas and opinions (SAIO) & 0.8602 \\
6. Recognising employees' involvement and accomplishments (REIA) & 0.8245 \\
\hline
\end{tabular}

\subsection{Content validity of the EPS}

Validity is defined as the extent to which any measuring instrument measures what it is indented to measure ${ }^{[3]}$. Content validity depends on the extent to which an empirical measurement reflects a specific domain of content. This is a subjective measure of how appropriate the items seem to various reviewers who have some knowledge of the subject matter ${ }^{[25]}$. Although content validity cannot be evaluated numerically, it provides a solid foundation on which a methodologically rigorous assessment of a survey instrument's validity can be performed.

The content validity of the EPS constructs is determined by matching each construct to 21 points of effectiveness ${ }^{[21]}$ and 20 categories used in the Minnesota Perception Survey ${ }^{[22]}$. The matching results are summarised in Tab. 4. Each perception construct is linked to the corresponding point of effectiveness and category, which it represents. In total, the EPS constructs are represented by 24 different points of effectiveness and categories.

The content validity of these items can be further verified by linking them to the scale items used by Likert ${ }^{[17,18]}$ in measuring employee's perceptions. Tab. 5 shows the link of the EPS variables and corresponding items to the organisational and performance characteristics. CTO's item numbers 3, 9, 12, 19, 33, 36, 46 and 52 can be matched directly 
Table 4. Matching the EPS constructs with Peterson's 21 points of effectiveness and categories of the Minnesota Perception Survey

\begin{tabular}{|c|c|c|}
\hline EPS Construct & $\begin{array}{l}\text { Peterson's } 21 \text { points } \\
\text { of Effectiveness [21] }\end{array}$ & $\begin{array}{l}\text { Minnesota Perception } \\
\text { Survey Categories [22] }\end{array}$ \\
\hline \multirow{5}{*}{$\begin{array}{l}\text { 1. Confidence and trust } \\
\text { in the organisation (CTO) }\end{array}$} & 1. Management's real credibility & 1. Credibility \\
\hline & 2. General attitudes of employees & 2. Attitudes \\
\hline & 3. Positive safety culture & 3. Climate \\
\hline & 4. Daily stress & - \\
\hline & $\longrightarrow$ & 4. Motivation \\
\hline \multirow{5}{*}{$\begin{array}{l}\text { 2. Interest in the } \\
\text { employees' future (IEF) }\end{array}$} & 5. Employees training & 5. Training \\
\hline & 6. Support for safety & \multirow[b]{2}{*}{ 6. Support } \\
\hline & 7. Handling of new worker & \\
\hline & 8. Alcohol and drug problems & 7. Substance abuse \\
\hline & - & 8. Employment \\
\hline \multirow{5}{*}{$\begin{array}{l}\text { 3. Teaching employees to } \\
\text { solve problems (TESP) }\end{array}$} & 9. Operating practices & $\longrightarrow$ \\
\hline & 10. Effective supervisory training & 9. Supervisory training \\
\hline & 11. Safety contacts & $\longrightarrow$ \\
\hline & 12. Inspections & 10. Inspections \\
\hline & 13. Hazard correction procedure & 11. Hazard correction \\
\hline \multirow{6}{*}{$\begin{array}{l}\text { 4. Communicating information and } \\
\text { needs in the organisation (CINO) }\end{array}$} & 14. Accident investigation process & 12. Investigations \\
\hline & 15. Perception of quality of supervisors & $\longrightarrow$ \\
\hline & 16. Communication effectiveness & 13. Communication \\
\hline & 17. Awareness programs & 14. Regulations \\
\hline & $\longrightarrow$ & 15. Supervision \\
\hline & 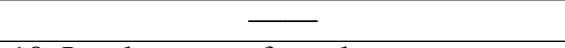 & 16. Meetings \\
\hline \multirow{2}{*}{$\begin{array}{l}\text { 5. Actively seeking for employees' } \\
\text { ideas and opinions (ASIO) }\end{array}$} & 18. Involvement of employees & 17. Involvement \\
\hline & 19. Goal setting process & 18. Goals \\
\hline \multirow{2}{*}{$\begin{array}{l}\text { 6. Recognising employees' involvement } \\
\text { and accomplishments (REIA) }\end{array}$} & 20. Discipline policies & 19. Discipline \\
\hline & 21. Worker recognition & 20. Recognition \\
\hline
\end{tabular}

by Likert's ${ }^{[17]}$ item numbers $1 \mathrm{c}, 6 \mathrm{~b}, 5 \mathrm{c}, 6 \mathrm{~d}, 6 \mathrm{c}, 1 \mathrm{~g}, 3 \mathrm{a}$ and 1f, respectively. Similarly, most of the EPS construct's item numbers can be matched to at least one of Likert's item numbers. Only the EPS's item numbers 28 and 2 are not matched, while item number 11 is matched by Likert's item numbers $2 \mathrm{a}$ and $2 \mathrm{~d}$. The results indicate that EPS is a valid and reliable measure of employees' perceptions with regard to continual improvement.

\subsection{Construct validity of the EPS}

The perceptions are hypothesised as the latent factors that are measured by the six EPS variables or constructs (as listed in Tab. 1). The Confirmatory Factor Analysis was used to analyse the hypothesized measurement models of these constructs. Tab. 4 summarises the findings of the CFA with respect to the factor loadings, squared multiple correlations $R^{2}$ and the $t$-values of the employee perception questions (EPQ) in the survey. Results show that the factor loadings could act as validity coefficients as most measurements (with the exception of REIA) represent a good fit to the data collected.

The following is a summary of the validity test of six EPS constructs for the employees' perception measures:

- For the CTO measurement, the degree of freedom is 20 with a minimum fit function chi-square value of 34.689 (i.e. $p=0.0218$ ). This represents a good fit.

- For the IEF measurement, the degree of freedom is 9 with a minimum fit function chi-square value of 19.085 (i.e. $p=0.0245)$. This represents a good fit.

- For the TESP measurement, the degree of freedom is 20 with a minimum fit function chi-square value of 35.581 (i.e. $p=0.0172$ ). This represents a good fit.

- For the CINO measurement, the degree of freedom is 14 with a minimum fit function of 19.778 (i.e. $p=0.0137$ ). This represents a good fit.

- For the ASIO measurement, the degree of freedom is 20 with a minimum fit function chi-square value of 35.227 (i.e. $p=0.0189$ ). This represents a good fit.

- For the REIA measurement, the degree of freedom is 5 with a minimum fit function chi-square value of 16.866 (i.e. $p=0.00476$ ). This represents a fairly good fit. 
While looking into the validity coefficients of individual EPS constructs, results show that the corresponding employee perception questions have high or fairly high factor loadings, $R^{2}$ values and $t$-values. This indicates that the six EPS constructs have a reasonably high degree of construct validity. This can be elaborated as follows:

Table 5: Linking EPS variables with Likert's operating characteristics and scales

\begin{tabular}{|c|c|c|}
\hline $\begin{array}{l}\text { Employee Perception } \\
\text { Survey Variables }\end{array}$ & EPS Item No. & Likert's operating characteristics and corresponding item number \\
\hline \multirow{8}{*}{$\begin{array}{l}\text { 1. Confidence and trust } \\
\text { in the organisation (CTO) }\end{array}$} & 3 & $\begin{array}{l}\text { 1c. Attitudes generally are strongly favourable and } \\
\text { provide powerful stimulation to behaviour implementing } \\
\text { organisation's goals }\end{array}$ \\
\hline & 15 & $\begin{array}{l}\text { 6b. Strong pressures to obtain complete and accurate } \\
\text { information to guide own behavior, hence information and } \\
\text { measurements tend to be complete and accurate }\end{array}$ \\
\hline & 27 & 5c. Goals are fully accepted both overtly and covertly \\
\hline & 37 & $\begin{array}{l}\text { 6d. Informal and formal groups are one and the same, hence all } \\
\text { social forces support efforts to achieve organisation's goals }\end{array}$ \\
\hline & 40 & $\begin{array}{l}\text { 6c. Quite widespread responsibility for review and control, with } \\
\text { employees at times imposing more rigorous and tighter } \\
\text { controls than top management }\end{array}$ \\
\hline & 26 & $\begin{array}{l}\text { 1g. Relatively high satisfaction throughout the organisation with } \\
\text { regard to membership in the organisation, supervision, } \\
\text { and one's own achievements }\end{array}$ \\
\hline & 4 & $\begin{array}{l}\text { 3a. Amount and character of information extensive, } \\
\text { friendly with high degree of confidence and trust }\end{array}$ \\
\hline & 14 & $\begin{array}{l}\text { 1f. Favorable, cooperative attitudes throughout the organisation } \\
\text { with mutual trust and confidence }\end{array}$ \\
\hline \multirow{6}{*}{$\begin{array}{l}\text { 2. Interest in the } \\
\text { employees' future (IEF) }\end{array}$} & 16 & $\begin{array}{l}\text { 2f. Top management know and understand problems faced } \\
\text { by employees }\end{array}$ \\
\hline & 28 & $\longrightarrow$ \\
\hline & 5 & $\begin{array}{l}\text { 5b. Employees strive for high performance goals sometimes } \\
\text { higher than top management }\end{array}$ \\
\hline & 36 & $\begin{array}{l}\text { 4d. Technical and professional knowledge used in decision-making } \\
\text { is available anywhere }\end{array}$ \\
\hline & 25 & $\begin{array}{l}4 \mathrm{e} 2 . \text { There is substantial contribution by decision-making processes } \\
\text { to motivate to implement }\end{array}$ \\
\hline & 13 & $\begin{array}{l}\text { 4e1. Employees used in group decision processes to } \\
\text { make available the } \\
\text { most adequate and accurate information bearing on } \\
\text { decision making }\end{array}$ \\
\hline \multirow{9}{*}{$\begin{array}{l}\text { 3. Teaching employees to } \\
\text { solve problems (TESP) }\end{array}$} & 6 & $\begin{array}{l}\text { 1d. Motivational forces generally reinforce each other in a } \\
\text { substantial and cumulative manner }\end{array}$ \\
\hline & 17 & $\begin{array}{l}\text { 6a. Concern for performance of control function is likely to be felt } \\
\text { throughout the organisation }\end{array}$ \\
\hline & 29 & $\begin{array}{l}\text { 1e. Employees feel real responsibility for organisation's goals and } \\
\text { are motivated to behave in ways to improve them }\end{array}$ \\
\hline & 2 & $\longrightarrow$ \\
\hline & 35 & $\begin{array}{l}\text { 3d. Supervisors have substantial but indirect influence over the goals, } \\
\text { activities, by building effective interaction- influence system }\end{array}$ \\
\hline & 24 & $\begin{array}{l}\text { 3b. Very substantial amount of cooperative teamwork throughout } \\
\text { the organisation }\end{array}$ \\
\hline & 12 & $\begin{array}{l}\text { 4f. Decision-making is largely based on group pattern, and } \\
\text { encourages teamwork }\end{array}$ \\
\hline & 7 & $\begin{array}{l}\text { 3e. Capacity for information to flow in all directions from } \\
\text { all levels and for appropriate influence to be exerted }\end{array}$ \\
\hline & 18 & $\begin{array}{l}2 \mathrm{~d} 2 \text {. Considerable responsibility felt and much initiative } \\
\text { communicates all relevant information }\end{array}$ \\
\hline
\end{tabular}


Table 5: Continued

\begin{tabular}{|c|c|c|}
\hline \multirow{6}{*}{$\begin{array}{l}\text { 4. Communicating } \\
\text { information and } \\
\text { needs in the } \\
\text { organisation (CINO) }\end{array}$} & 30 & $\begin{array}{l}\text { 2e. Sideward communication's adequacy and accuracy good } \\
\text { to excellent }\end{array}$ \\
\hline & 38 & $\begin{array}{l}2 \mathrm{~d} 3 \text {. Virtually no forces to distort and powerful } \\
\text { forces to communicate accurately }\end{array}$ \\
\hline & 34 & $\begin{array}{l}\text { 4b. Relatively complete and accurate information available } \\
\text { based both on measurements and efficient flow of information }\end{array}$ \\
\hline & 23 & 2d4. Accurate upward communication \\
\hline & \multirow{2}{*}{11} & $\begin{array}{l}\text { 2a. Much interaction and communication aimed at achieving } \\
\text { organisation's objectives }\end{array}$ \\
\hline & & 2d5. No need for supplementary upward communication \\
\hline \multirow{7}{*}{$\begin{array}{l}\text { 5. Actively seeking for } \\
\text { employees' ideas } \\
\text { and opinions (ASIO) }\end{array}$} & 1 & 2c1. Downward communication initiated at all levels \\
\hline & 19 & 2b. Direction of information down, up and with peers \\
\hline & 31 & $\begin{array}{l}\text { 2c2. Downward communication generally accepted, } \\
\text { but if not, openly and candidly questioned }\end{array}$ \\
\hline & 33 & $\begin{array}{l}\text { 4c. Top management is aware of problems, particularly } \\
\text { those at lower levels of the organisation }\end{array}$ \\
\hline & 8 & 2d1. A great deal of Upward communication \\
\hline & 22 & $\begin{array}{l}\text { 5a. Except in emergencies goals are usually established } \\
\text { by means of group participation }\end{array}$ \\
\hline & 10 & $\begin{array}{l}\text { 4a. Decision making widely done throughout the organisation, } \\
\text { although well integrated through linking process }\end{array}$ \\
\hline \multirow{5}{*}{$\begin{array}{l}\text { 6. Recognising } \\
\text { employees' } \\
\text { involvement and } \\
\text { accomplishments } \\
\text { (REIA) }\end{array}$} & 20 & $\begin{array}{l}\text { 1b. Economic rewards based on compensation system developed } \\
\text { through participation }\end{array}$ \\
\hline & 32 & $\begin{array}{l}3 \mathrm{c} 1 . \text { Superiors see the extent to which employees influence } \\
\text { the goals, methods, and activities of the organisation }\end{array}$ \\
\hline & 39 & $\begin{array}{l}3 \mathrm{c} 2 . \text { Employees see the extent to which other employees influence the } \\
\text { goals, methods, and activities of the organisation }\end{array}$ \\
\hline & 21 & $\begin{array}{l}\text { 2f1. The perceptions of supervisors and employees are } \\
\text { usually quite accurate }\end{array}$ \\
\hline & 9 & 1a. Full use of economic, ego, and other major motives \\
\hline
\end{tabular}

- For the CTO measurement, the EPQs 3, 9, 19, 20, 33, 36, 46, and 52 are valid measures of CTO. The factor loadings have an average of 0.891 and range from a low of 0.814 for EPQ 20 to a high of 0.973 for EPQ 9 with corresponding values of $R^{2}$ being 0.663 and 0.948 .

- For the IEF measurement, the EPQs 6, 7, 31, 34, 35, and 51 are valid measures of IEF. The factor loadings have an average of 0.801 and range from a low of 0.696 for EPQ 34 to a high of 0.918 for EPQ 7 with corresponding values of $R^{2}$ being 0.484 and 0.842 .

- For the TESP measurement, the EPQs 1, 2, 14, 18, 21, 24, 27, and 47 are valid measures of TESP. The factor loadings have an average of 0.877 and range from a low of 0.797 for EPQ 47 to a high of 0.959 for EPQ 21 with corresponding values of $R^{2}$ being 0.635 and 0.920 .

- For the CINO measurement, the EPQs 8, 13, 23, 29, 30, 32, 41 are valid measures of CINO. The factor loadings have an average of 0.840 and range from a low of 0.476 for EPQ 32 to a high of 0.973 for EPQ 8 with corresponding values of $R^{2}$ being 0.226 and 0.947 .

- For the ASIO measurement, the EPQs 4, 11, 16, 26, 28, 40, 43 and 53 are valid measures of ASIO. The factor loadings have an average of 0.859 and range from a low of 0.721 for EPQ 40 to a high of 0.965 for EPQ 4 with corresponding values of $R^{2}$ being 0.520 and 0.931 .

- For the REIA measurement, the EPQs 10, 17, 22, 38, and 39 are valid measures of REIA. The factor loadings have an average of 0.828 and range from a low of 0.707 for EPQ 38 to a high of 0.970 for EPQ 22 with corresponding values of $R^{2}$ being 0.500 and 0.941 .

\section{Conclusion}

This paper addresses the problem of insufficient research on identifying standard constructs and measuring employees' perceptions towards the continual quality improvement of SMEs. It proposes a self-assessment scale, EPS, to measure employees' perception while implementing a quality management system. The scale comprises six EPS variables or constructs and forty-six criteria that could facilitate the TQM implementation in SMEs. Empirical evidence 
Table 6. Confirmatory factor analysis of the six latent constructs of the EPS

\begin{tabular}{|c|c|c|c|c|c|c|c|c|c|}
\hline $\begin{array}{l}\text { Latent } \\
\text { Construct } \\
\end{array}$ & EPQ No. & $\begin{array}{l}\text { Factor } \\
\text { loadings }\end{array}$ & $R^{2}$ & $t$-values & $\begin{array}{l}\text { Latent } \\
\text { Construct }\end{array}$ & EPQ No. & $\begin{array}{l}\text { Factor } \\
\text { loadings }\end{array}$ & $R^{2}$ & $t$-values \\
\hline \multirow{8}{*}{ СТО } & 3 & 0.957 & 0.915 & 34.933 & \multirow{7}{*}{ CINO } & 8 & 0.973 & 0.947 & 40.611 \\
\hline & 9 & 0.973 & 0.948 & 41.931 & & 13 & 0.957 & 0.916 & 44.162 \\
\hline & 19 & 0.911 & 0.830 & 23.258 & & 23 & 0.906 & 0.820 & 26.718 \\
\hline & 20 & 0.814 & 0.663 & 12.696 & & 29 & 0.944 & 0.892 & 29.073 \\
\hline & 33 & 0.824 & 0.679 & 15.781 & & 30 & 0.959 & 0.920 & 25.025 \\
\hline & 36 & 0.856 & 0.732 & 15.236 & & 32 & 0.476 & 0.226 & 4.622 \\
\hline & 46 & 0.897 & 0.804 & 30.329 & & 41 & 0.668 & 0.447 & 9.074 \\
\hline & 52 & 0.897 & 0.805 & 21.937 & \multirow{8}{*}{ ASIO } & 4 & 0.965 & 0.931 & 46.483 \\
\hline \multirow{6}{*}{ IEF } & 6 & 0.713 & 0.508 & 6.868 & & 11 & 0.929 & 0.864 & 31.409 \\
\hline & 7 & 0.918 & 0.842 & 19.119 & & 16 & 0.939 & 0.882 & 37.360 \\
\hline & 31 & 0.844 & 0.712 & 10.621 & & 26 & 0.741 & 0.548 & 10.447 \\
\hline & 34 & 0.696 & 0.484 & 6.313 & & 28 & 0.857 & 0.735 & 20.135 \\
\hline & 35 & 0.734 & 0.538 & 8.746 & & 40 & 0.721 & 0.520 & 16.044 \\
\hline & 51 & 0.899 & 0.808 & 19.674 & & 43 & 0.839 & 0.704 & 16.808 \\
\hline \multirow{8}{*}{ TESP } & 1 & 0.928 & 0.860 & 24.993 & & 53 & 0.879 & 0.773 & 22.147 \\
\hline & 2 & 0.918 & 0.843 & 32.443 & \multirow{7}{*}{ REIA } & 10 & 0.818 & 0.670 & 13.375 \\
\hline & 14 & 0.955 & 0.912 & 48.904 & & 17 & 0.886 & 0.786 & 13.896 \\
\hline & 18 & 0.803 & 0.645 & 12.978 & & 22 & 0.970 & 0.941 & 25.922 \\
\hline & 21 & 0.959 & 0.920 & 50.155 & & 38 & 0.707 & 0.500 & 9.785 \\
\hline & 24 & 0.849 & 0.721 & 19.148 & & 39 & 0.760 & 0.577 & 8.116 \\
\hline & 27 & 0.803 & 0.645 & 15.760 & & & & & \\
\hline & 47 & 0.797 & 0.635 & 15.495 & & & & & \\
\hline
\end{tabular}

was acquired from 635 respondents of 110 SMEs operating in Trinidad and Tobago. The inter-item reliability of the EPS in measuring its hypothesised constructs was determined by their collective Cronbach Alpha values. Contrasting the philosophies in the literature built relevant insights on the content validity. The construct validity was empirically determined using the CFA. The research findings verified the factor loadings, $R^{2}$ values and $t$-values and determined the validity of the hypothesised relationships between the scale items and their constructs.

It is evident that the EPS is a useful measure of employees' perception with regard to the maturity of quality management system implementation in SMEs. The EPS is of practical use to practitioners who seek for continual quality performance in their organisations. SMEs could use the EPS to determine the extent to which the six latent variables or constructs are implemented. Future research would validate the importance of individual EPS constructs on measuring employee perception towards quality performance improvement in SMEs. Strategic improvement objectives for each construct could be formulated by closer examination on each EPQ item and areas of improvement could be identified and prioritised.

\section{References}

[1] ISO 9001: Quality Management Systems - Requirements, year = 2000. International Organisation of Standardisation.

[2] Focus available at: http:/www.iso.ch/iso/en/commcentre/isofocus/guestviews/0609_rasin.pdf. Focus available at: http:/www.iso.ch/iso/en/commcentre/isofocus/guestviews/0609_rasin.pdf, 2007.

[3] R. Adcock, D. Collier. Measurement validity: A shared standard for qualitative and quantitative research. American Political Science Review, 2001, 95(529-546).

[4] P. Bentler, C. Chow. Practical issues in multivariate analysis. Sociological Methods and Research, 1987, 16(78117).

[5] A. Chennell, S. Dransfield, et. al. Opm: a system for organisational performance measurement. in: Proceedings of the Performance Measurement - Past, Present, and Future Conference, 2000.

[6] P. Garengo, S. Biazzo, U. Bititci. Performance measurement systems in SMEs: A review for a research agenda. International Journal of Management Reviews, 2005, 7(1): 25-47.

[7] A. Ghobadian, D. Gallear. TQM and organisation size. International Journal of Quality and Reliability Management, 1997, 17(3): 121-163.

[8] J. Hair, R. Anderson, et. al. Multivariate Data Analysis. Prentice Hall, 1995. 
[9] G. Johns, A. Saks. Orgnisational Behavior: Understanding and Managing Life at Work. Addison Wesley Longman, 1997.

[10] K. Joreskog, D. Sorbom. Prelis 2: User's reference guide. Scientific Software International, 2002.

[11] E. Laitinen. A dynamic performance measurement system: evidence from small finnish technology companies. Scandinavian Journal of Management, 2002, 18: 55-59.

[12] W. Lewis, K. Pun, T. Lalla. An AHP analysis of QMPs of ISO 9004: 2000 in ISO 9001: 2000 certified SMEs in Trinidad and Tobago. The International Journal of INGENIUM, 2005, 3: 73-82.

[13] W. Lewis, K. Pun, T. Lalla. An empirical study of ISO 9004: 2000 maturity of ISO 9001certified SME in Trinidad and Tobago. The Asian Journal on Quality, 2005, 6(3): 190-203.

[14] W. Lewis, K. Pun, T. Lalla. Empirical investigation of the hard and soft criteria of TQM in ISO 9001-certified small and medium-sized enterprises. International Journal of Quality and Reliability Management, 2006, 23(9): 964-984.

[15] W. Lewis, K. Pun, T. R. M. Exploring soft versus hard factors for TQM implementation in small and medium-sized enterprises. International Journal of Productivity and Performance Management, 2006, 55(7): 539-554.

[16] W. Lewis, K. Pun, T. R. M. Measuring the reliability and validity of two scales for quality performance in SMEs: an empirical study. International Journal of Quality and Standards, 2007, 1(1).

[17] R. Likert. New Pattern of Management. McGraw-Hill, New York, 1961.

[18] R. Likert. The Human Organisation: Its Management and Value. McGraw-Hill, New York, 1967.

[19] J. Nunnally. Psychometric Theory. McGraw-Hill, New York, 1978.

[20] R. Pech, B. Slade. Employee disengagement: is there evidence of a growing problem? Handbook of Business Strategy, 2006, 7(1): 21-25.

[21] D. Peterson. What measures should we use, and why? measuring safety system effectiveness. Professional Safety, 1998, 37-40.

[22] D. Peterson. Safety management: A human approach. American Society of Safety Engineers, 2001.

[23] R. Schumackar, R. Lomax. A Beginner's Guide to Structural Equation Modelling. Lawrence Erlbaum Associates, 2004.

[24] J. Tasker. Engagement equals productivity. Personnel Today Magazine, 2004, 8-9.

[25] Z. Zhang, A. Waszink, J. Wijngaard. An instrument for measuring TQM implementation for chinese manufacturing companies. International Journal of Quality \& Reliability Management, 2000, 17(7): 730-755. 